\title{
Effects of a maternal role adjustment program for first time mothers who use postpartum care centers (Sanhujoriwon) in South Korea: a quasi-experimental study
}

Ju-Eun Song ${ }^{1}$, Hyun-Ju Chae ${ }^{2^{*}}$, Jung Mi Ko ${ }^{3,4}$, Jeong In Yang ${ }^{5}$ and Tiffany Kim ${ }^{6}$

\begin{abstract}
Background: Many South Korean women stay in specialized postpartum care centers called Sanhujoriwon for 2 weeks after childbirth, a time which is widely recognized as a critical period for maternal role adjustment. Mothers' time within the postpartum care center offers a unique opportunity for nursing intervention to promote a successful transition to motherhood, especially for first time mothers. This study aimed to develop a maternal role adjustment program within the Sanhujoriwon based on the ecological model, and to evaluate its effects on maternal role confidence and breastfeeding success.
\end{abstract}

Methods: A non-equivalent control group pretest-posttest design was used. Data were collected from 30 participants in the experimental group and 37 in the control group at four measurement times, i.e., admission day to Sanhujoriwon, discharge day from Sanhujoriwon, 4-6 weeks postpartum, and 12 weeks postpartum. The experimental group received the maternal role adjustment program, which included family education and counseling regarding breastfeeding and infant care, and encouraged rooming-in practices during their stay in the Sanhujoriwon. The data were analyzed using the IBM SPSS statistics 25.0 program using descriptive statistics, t-test, chi-square test, ANCOVA, and GEE.

Results: There were significant interaction effects showing different patterns in maternal role confidence and breastfeeding success scores over the four time points. Maternal role confidence in the experimental group gradually increased over time. Maternal role confidence in the control group also increased from baseline to 4 to 6 week postpartum, but abruptly decreased at 12 week postpartum. At 12 weeks postpartum, maternal role confidence in the experimental group was significantly higher than that of the control group. In addition, breastfeeding success scores in the experimental group also gradually increased over the four time points, while those of the control group showed a gradual decline. Breastfeeding success scores were significantly higher than those of control group at both 4-6 weeks and 12 weeks postpartum.

Conclusions: These results indicate that the maternal role adjustment program was effective in improving maternal role confidence and breastfeeding success among first time mothers in the postpartum care center.

Keywords: Mothers, Maternal behavior, Breastfeeding, Ecology

\footnotetext{
* Correspondence: himnp@hanmail.net

2Department of Nursing, Joongbu University, 201, Daehak-ro, Chubu-myeon,

Geumsan-gun, Chungnam 32713, Republic of Korea

Full list of author information is available at the end of the article
}

\section{$\triangle B M C$}

(c) The Author(s). 2020 Open Access This article is licensed under a Creative Commons Attribution 4.0 International License, which permits use, sharing, adaptation, distribution and reproduction in any medium or format, as long as you give appropriate credit to the original author(s) and the source, provide a link to the Creative Commons licence, and indicate if changes were made. The images or other third party material in this article are included in the article's Creative Commons licence, unless indicated otherwise in a credit line to the material. If material is not included in the article's Creative Commons licence and your intended use is not permitted by statutory regulation or exceeds the permitted use, you will need to obtain permission directly from the copyright holder. To view a copy of this licence, visit http://creativecommons.org/licenses/by/4.0/ The Creative Commons Public Domain Dedication waiver (http://creativecommons.org/publicdomain/zero/1.0/) applies to the data made available in this article, unless otherwise stated in a credit line to the data. 


\section{Background}

The postpartum period is a time of great vulnerability for many women [1]. Throughout the world, many culturally-specific traditional care practices for postpartum women are observed to ensure recovery and avoid health problems in later years [2].

In South Korea, postpartum women were traditionally provided with care in homes called Sanhujori for 2-3 weeks following delivery by non-professional caregivers such as their mother or mother-in-law [3]. But recent societal changes to the extended nuclear family system and increased postpartum care needs have made traditional Sanhujori in homes difficult to maintain. This has driven the emergence of stand-alone postpartum care center called Sanhujoriwon [4]. These are nonmedical commercial facilities, where women and infants stay for a couple of weeks right after discharge from the hospital. Sanhujoriwon first emerged in 1996 and their numbers and utilization have dramatically increased since that time [5]. In 2018, a total of 584 of these facilities were in operation [5]. According to recent Korean national statistic, 75\% of delivering women in South Korea used Sanhujoriwon in 2018 [6]. Sanhujoriwon continue be an important part of postpartum care for women and their infants in South Korea and are only expected to increase in number in the coming years [4-6].

However, it appears that Sanhujoriwon have some significant problems in maternity care management, particularly related to breastfeeding success, family-infant bonding and overall infant care ability. Although childbirth and parenthood is a family-centered phenomenon and family centered care is widely recognized as the global standard of care during the postpartum period [7-9], rooming-in is not currently the norm within Sanhujoriwon $[6,10]$. Not surprisingly, this environment is associated with decreased breastfeeding success and increased parental stress after discharge from Sanhujoriwon [10, 11]. According to a national survey in 2018 regarding Sanhujoriwon use, only $3 \%$ of postpartum women using Sanhujoriwon "roomed in" with their infants for $24 \mathrm{~h}$ and the

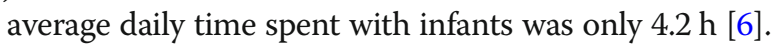

Many mothers view their postpartum stay within the Sanhujoriwon as an opportunity for rest and recovery without parenting responsibilities [11]. Therefore many mothers in Sanhujoriwon do not desire to room-in and are separated from their babies most of the time [10, 11]. Likewise, most Sanhujoriwon engage in rooming-in practices only if mothers specifically request it in order to promote sufficient rest for new mothers [10]. Also Sanhujoriwon commonly limit the presence of family members except partners for infection control. Accordingly, partners are the primary source of family support to mothers in the Sanhujoriwon, but they usually also need support and education for parenting role adjustment [11]. Therefore, most mothers in Sanhujoriwon spend their early postpartum period without sufficient mother-infant interaction and social support from family members to assist in a successful maternal transition to motherhood in the early period after childbirth $[10,11]$.

Mother-infant interaction and social support are important influencing factors on maternal role adjustment for the first time mother [11, 12]. So lessening these opportunities within the Sanhujoriwon may have a negative impact on infant care ability and breastfeeding success of first time mothers. Previous studies to explore the effect of Sanhujoriwon use reported that parenting stress and postpartum depression were higher in mothers who used Sanhujoriwon than mothers who did not use it after discharge from Sanhujoriwon [11, 13]. A qualitative study on experiences of Sanhujoriwon use also showed that first time mothers who stayed in Sanhujoriwon had more difficulty breastfeeding and providing infant care after discharge [10]. Since the use of Sanhujoriwon is expected to continue to rise [4-6], it is imperative that interventions for promoting maternal role adjustment be developed and implemented. It will be especially important to focus these family centered interventions on infant care and breastfeeding during this critical maternal transition period within the Sanhujoriwon [10, 11, 13].

Several intervention studies for promoting maternal role adjustment of mothers in Sanhujoriwon have been published [14]. Most of these studies provided educational interventions focused on parenting knowledge and skill to mothers without partners and didn't fully consider the family unit approach or the environmental characteristics of the Sanhujoriwon [15-17].

Bronfenbrenner's ecological system model [18] provides a robust theoretical foundation for the family unit approach within the environment of the Sanhujoriwon, as it allows for inclusion of a multitude of environmental factors surrounding individuals. The ecological model can help explain human behavior and development [19] and has been used in previous studies to explain parenting stress or development [20-22]. The ecological model posits that an individual's development is influenced by various environment system surrounding individuals [18, 23]. According to the ecological model, the mother's development or behavior is not only affected by her own characteristics (the individual level), but also by the various settings of her immediate environment (the microsystem level), such as partner and her baby, and by the interrelationships amongst the settings of her immediate environments (the mesosystem level). The mother's behavior is further influenced by the broader social setting (the exosystem level), such as family centered care system and care principles for family supports in the Sanhujoriwon. These, in turn, are influenced by cultural value or belief toward family centered care practices in 
the Sanhujoriwon (the macrosystem level) [18]. A mother's adjustment could be enhanced by maximizing the healthy effects of all the various systems within the ecological model.

To our knowledge, this is the first intervention study focused on maternal role adjustment for first time mothers using Sanhujoriwon based on the ecological model. In this paper, we present a family-centered care education and counseling intervention encouraging infant care practices and breastfeeding while rooming-in with mothers and partners, and evaluate its effect on maternal role confidence and breastfeeding success.

\section{Methods}

\section{Design}

A non-equivalent control group pretest posttest and repeated measure design was used to compare the effects of maternal role adjustment program for primiparous women who use Sanhujoriwon on maternal role confidence for infant care and breastfeeding success. Using a quasi-experimental design, we first recruited participants for the control group and collected their data before implementing the intervention. We then subsequently recruited participants for the experimental group, delivered the intervention, and collected data from them at different time points. Thus randomized sampling can't be achieved. However, we believe that this time difference allowed us to prevent any diffusion of the intervention between the control and experimental groups.

In this study, data were measured at four times; $2 \sim 7$ days after childbirth, i.e., the admission day to Sanhujoriwon (baseline), two to 3 weeks after childbirth, i.e., the discharge day from Sanhujoriwon (posttest 1), 4 to 6 week postpartum (posttest 2), and 12 week postpartum (posttest 3 ).

\section{Participants}

All participants were recruited through convenience sampling from two Sanhujoriwon. Participants were included if they: (1) were primiparous women who delivered a healthy infant weighing over $2500 \mathrm{~g}$ after 37 weeks gestation, (2) were admitted to the Sanhujoriwon together with their infants, and (3) voluntarily agreed to participate in this study together with their partner. Exclusion criteria were first time mothers who (1) delivered twins, or (2) had health problems including infection, bleeding, or major depression during childbirth and postpartum period, and needed medical treatments in the Sanhujoriwon.

The study sample initially included 40 participants in the control group and 39 participants in the experimental group. In the control group, three participants failed to complete the study because of withdrawal at posttest2 $(n=2)$ and the follow-up loss at posttest3 $(n=1)$. While nine participants from the experimental group failed to finish the study because of loss to follow up at posttest2 $(n=3)$ and posttest3 $(n=6)$. Finally, 37 participants in the control group and 30 mothers in experimental group were included in the final sample, resulting in an attrition rate of $15.2 \%$ (12 participants). To check whether the retained sample was biased from the initial sample or not, baseline comparisons were undertaken between mothers lost to follow-up and those retained in the study [24]. There were no significant differences in demographic characteristics such as age, family type, education, occupation, economic status, delivery type, baby gender, and baby's birth weight between dropouts and the study sample. The retained sample does not appear to differ from those lost to follow up and does not impact our study findings [24].

The total participant number of this study $(N=67)$ exceeds the required minimum sample size $(N=24)$ calculated by the $\mathrm{G}^{*}$ power 3.1 program [25] with an alpha of 0.05 , power of 0.80 , and medium effect size for variance test of $0.25,2$ groups and 4 repeated measurements.

\section{Intervention}

The maternal role adjustment program was developed based on the ecological model [18] and previous research regarding care needs of postpartum women using Sanhujoriwon [10]. The overall research framework for this study is presented in Fig. 1.

According to the ecological model [18], individuals' behavior is influenced by various multi-level environments surrounding individuals such as the microsystem, mesosystem, exosystem, and macrosystem. Therefore, we considered various factors within each system in the maternal role adjustment program.

For the individual level, group and individual education were provided to mothers. The main goal of this education was to improve mothers' knowledge and skills regarding infant care and breastfeeding. This education also focused on cultivating a positive attitude related to rooming-in and breastfeeding. Individual counseling and coaching were also provided to facilitate parenting role practice for infant care and breastfeeding, and to address parenting challenges. In the microsystem level, partner education was conducted in order to equip them with improved knowledge and skills in infant care and breastfeeding support. As for the mesosystem level, healthy interactions between partners and their babies were encouraged to help build a more favorable family centered care environment. For the exosystem level, we worked with the Sanhujoriwon administrator to encourage and prioritize rooming-in and provide exclusive breastfeeding support in the Sanhujoriwon. Lastly, to address the macrosystem level, we tried to change the value regarding postpartum care, especially rooming-in choice and exclusive breastfeeding in the Sanhujoriwon through education and counseling. We taught that focusing on mother's rest with 


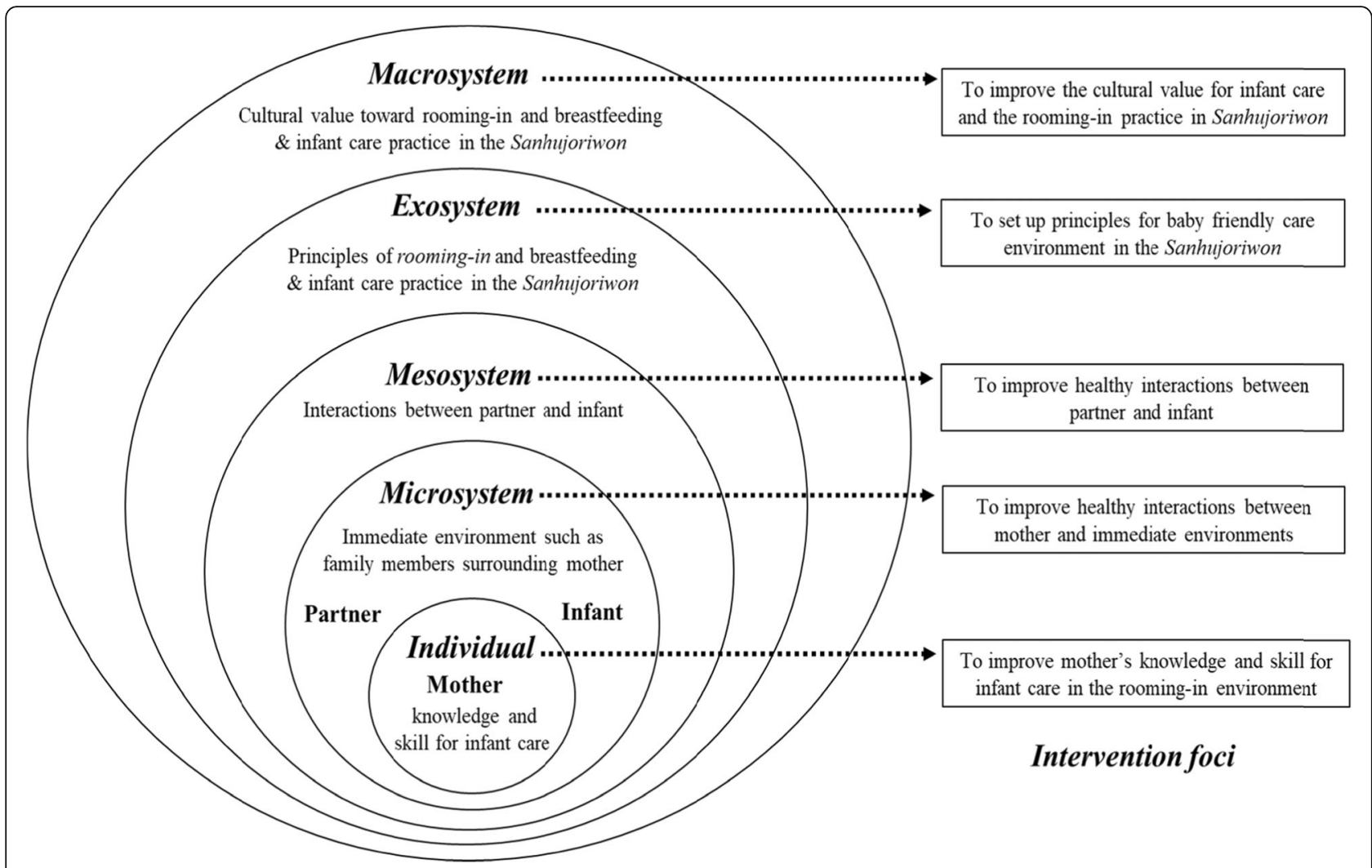

Fig. 1 Research framework to show intervention focus in each system for maternal role adjustment program

minimal parenting role practice has a negative effect on learning the parenting role, because the early period after childbirth is a very important period for parental role adjustment. Thus, rooming-in to improve interaction between parent and infant, and to create active learning opportunities for parenting role practice is basic and essential to a successful transition to parenthood. The intervention program based on the ecological model is presented in Table 1.

In summary, the intervention was designed to enhance the interactions amongst various support systems and to create a healthy family focused environment to promote infant care and breastfeeding practice. To this end, the authors set up a familycentered rooming-in support system for enhancing parent and infant interactions, and a supportive environment for breastfeeding within the Sanhujoriwon. We also encouraged partners to provide positive support for new mothers within the Sanhujoriwon. For this purpose, one individual orientation session, two group education sessions, and four individual family counseling \& coaching encounters were provided to participants. The intervention was delivered to the participants by 2 members of the research team: the principle investigator (PI), an expert in maternity and women's health nursing (JES), and a clinical expert in the women's health (JMK). In order to improve the internal validity of the intervention, JES and JMK met frequently to discuss the study. Details for intervention elements for each session including intervention provider are presented in Table 2 .

\section{Measurements}

Maternal role confidence was measured using the selfconfidence scale developed by Pharis [26]. This scale consisted of 10 items rated on a 5-point Likert scale (1-5), with higher scores indicating higher degrees of maternal confidence for infant care. The internal consistency reliability for this scale at four measurements in this study ranged from .718 to .912 .

Breastfeeding success was measured by one item with 5 grades about breastfeeding status based on the World Health Organization (WHO) definition of breastfeeding status [27]. This item has been reliably used to measure breastfeeding success in many other studies [28, 29]. According to the WHO, Grade 1 means exclusive breastfeeding, grade 2 means that breastfeeding is much more than formula feeding, grade 3 is the same proportion of breastfeeding and formula feeding, grade 4 means that formula feeding is much more than breast feeding, and grade 5 means exclusive formula feeding [29]. In this study, scores were presented reversed, as suggested by Park [28], so a higher score meant higher level of breastfeeding 
Table 1 The maternal role adaptation program based on the ecological model

\begin{tabular}{|c|c|c|c|c|}
\hline $\begin{array}{l}\text { Ecological } \\
\text { system }\end{array}$ & Meaning & Intervention focus & Intervention goal & Intervention content \\
\hline Individual & $\begin{array}{l}\text { People's own } \\
\text { characteristics such as } \\
\text { knowledge, skill, health } \\
\text { etc. }\end{array}$ & $\begin{array}{l}\text { First time mothers' } \\
\text { knowledge and skill for } \\
\text { infant care in the baby } \\
\text { friendly environment }\end{array}$ & $\begin{array}{l}\text { - To improve first time mothers' core } \\
\text { knowledge and skill for infant care and } \\
\text { successful breastfeeding practices } \\
\text { - To promote mothers' positive attitudes } \\
\text { about rooming-in and breastfeeding } \\
\text { practice }\end{array}$ & $\begin{array}{l}\text { - Importance of rooming-in } \\
\text { - Successful breastfeeding strategies } \\
\text { and breast care } \\
\text { - Infant care skills including bathing, } \\
\text { diaper changing, playing, } \\
\text { interpreting baby's cues etc. }\end{array}$ \\
\hline Microsystem & $\begin{array}{l}\text { Immediate environment } \\
\text { surrounding individual }\end{array}$ & $\begin{array}{l}\text { Interactions between } \\
\text { mother-partner and } \\
\text { mother-infant }\end{array}$ & $\begin{array}{l}\text { - To improve the attachment and } \\
\text { relationships between mother and infant } \\
\text { - To improve the healthy relationship } \\
\text { between mother and partner } \\
\text { - To promote and empower partners' } \\
\text { support through providing partners core } \\
\text { knowledge and skill for infant care and } \\
\text { breastfeeding support }\end{array}$ & $\begin{array}{l}\text { - Encourage infant massage by } \\
\text { mother } \\
\text { - Importance of family centered } \\
\text { care and rooming-in } \\
\text { - Importance of supporters' role in } \\
\text { successful transition to } \\
\text { motherhood } \\
\text { - Infant care including bathing, } \\
\text { diaper changing, playing, } \\
\text { interpreting baby's cues etc. }\end{array}$ \\
\hline Mesosystem & $\begin{array}{l}\text { Interactions between } \\
\text { individuals } \\
\text { in the immediate } \\
\text { environment }\end{array}$ & $\begin{array}{l}\text { Interactions between } \\
\text { partner and infant }\end{array}$ & $\begin{array}{l}\text { - To improve the attachment and } \\
\text { relationships between father and baby }\end{array}$ & $\begin{array}{l}\text { - Encourage infant massage by } \\
\text { father } \\
\text { - Meaning of baby's cues and } \\
\text { playing with baby }\end{array}$ \\
\hline Exosystem & $\begin{array}{l}\text { Principles to affect } \\
\text { relations and behavior } \\
\text { within each } \\
\text { environment system }\end{array}$ & $\begin{array}{l}\text { Principles of rooming-in } \\
\text { and breastfeeding \& in- } \\
\text { fant care support in } \\
\text { Sanhujoriwon }\end{array}$ & $\begin{array}{l}\text { - To set up desirable principles of rooming- } \\
\text { in and exclusive breastfeeding support to } \\
\text { establish family centered care environ- } \\
\text { ment in Sanhujoriwon with Director of } \\
\text { Sanhujoriwon }\end{array}$ & $\begin{array}{l}\text { - Rooming-in and breastfeeding } \\
\text { support and education policies for } \\
\text { mother and her family }\end{array}$ \\
\hline Macrosystem & $\begin{array}{l}\text { Values to affect social } \\
\text { interactions that are } \\
\text { embedded in each } \\
\text { environment system. }\end{array}$ & $\begin{array}{l}\text { Value toward rooming-in } \\
\text { and breastfeeding in the } \\
\text { Sanhujoriwon }\end{array}$ & $\begin{array}{l}\text { - To promote the value of rooming-in and } \\
\text { breastfeeding during the early postpar- } \\
\text { tum period as a critical period for mater- } \\
\text { nal role transition and adaptation in } \\
\text { Sanhujoriwon }\end{array}$ & $\begin{array}{l}\text { - Stress the importance of choosing } \\
\text { to room-in and breastfeed to pro- } \\
\text { mote a successful transition to } \\
\text { mother and father roles }\end{array}$ \\
\hline
\end{tabular}

success. This scale was included in the self-report questionnaire, and sufficient explanation about the meaning of each score was provided to participants.

\section{Data collection and ethical considerations}

Data were collected using a self-report questionnaire from April to August, 2014 at two Sanhujoriwon located in one metropolitan city in South Korea. To control the effects of confounding variables such as postpartum care principles for breastfeeding support and infant care [11], two Sanhujoriwon having a similar size and care policies for mother and infant were selected for this study. Also, to prevent diffusion of the intervention effect, data collection for the control group was done first, and then data collection for the experimental group was conducted. In this study, data collection for baseline and posttest 1 were done at the Sanhujoriwon, and data for posttest 2 and posttest 3 were collected in participant homes through a mail survey.

Before data collection, this research protocol was reviewed and approved by the Institutional Review Board in A hospital. Full information including research purpose, process, compensation for research participation, voluntary participation and withdrawal from the study were given to all participants, and then written informed consents were received from all participants.

\section{Data analysis}

The data were analyzed using the IBM SPSS 25.0 program (SPSS Inc., Chicago, IL, USA). The normality of the study variables were examined using the Kolmogorov-Smirnov test, with $p>.05$ indicating that the data were normally distributed. Descriptive and inferential statistics (independent $t$ test and chi-square test) were used to describe and test homogeneity of the participants' baseline general characteristics and study variables between experimental and control groups. Generalized Estimating Equations (GEE) were used to determine the changes in maternal role confidence and breastfeeding success in time trends (baseline and three more measurement times), differences of variables between groups, and interaction effects between groups and time trends. As post analysis, independent sample t-test was done to verify the differences of the maternal role confidence at each measurement point and the paired t-test was used to verify the differences of study variables amongst four measurement times. ANCOVA analysis was used to verify differences between breastfeeding success scores when adjusting baseline breastfeeding success score. 
Table 2 Summary of main elements of intervention

\begin{tabular}{|c|c|c|c|c|c|c|c|}
\hline When provided & Content & $\begin{array}{l}\text { Delivery } \\
\text { method }\end{array}$ & $\begin{array}{l}\text { Delivery } \\
\text { unit }\end{array}$ & $\begin{array}{l}\text { Delivery } \\
\text { setting }\end{array}$ & $\begin{array}{l}\text { Deliverer } \\
\text { (Provider) }\end{array}$ & $\begin{array}{l}\text { Exposure } \\
\text { quantity }\end{array}$ & $\begin{array}{l}\text { Time } \\
\text { span }\end{array}$ \\
\hline $\begin{array}{l}\text { Sanhujoriwon } \\
\text { admission day }\end{array}$ & $\begin{array}{l}\text { - Orientation for postpartum care center's care } \\
\text { policies for mother and baby and environment's } \\
\text { characteristics } \\
\text { - Orientation for maternal adaptation program and } \\
\text { obtaining the written consent form }\end{array}$ & $\begin{array}{l}\text { Explanation } \\
\text { Agreement }\end{array}$ & $\begin{array}{l}\text { Individual } \\
\text { family } \\
\text { (First time } \\
\text { mother and } \\
\text { her partner) }\end{array}$ & $\begin{array}{l}\text { Maternal } \\
\text { private room } \\
\text { in } \\
\text { Sanhujoriwon }\end{array}$ & $\begin{array}{l}\text { Coauthor } \\
\text { (JMK) }\end{array}$ & 1 session & $30 \mathrm{~min}$ \\
\hline $\begin{array}{l}\text { The 1st Saturday } \\
\text { after admission } \\
\text { into Sanhujoriwon }\end{array}$ & $\begin{array}{l}\text { - Core components for enhancing maternal/ } \\
\text { paternal and baby attachment } \\
\text { - Strategies for successful breastfeeding and infant } \\
\text { care when rooming-in } \\
\text { - Supporter's role to empower and help the } \\
\text { mother's successful transition } \\
\text { - Importance of mothers and fathers' positive } \\
\text { attitudes or values about rooming-in and breast- } \\
\text { feeding practice for family-centered care } \\
\text { environment }\end{array}$ & $\begin{array}{l}\text { Lecture } \\
\text { Practice }\end{array}$ & $\begin{array}{l}\text { Group } \\
\text { (First time } \\
\text { mothers and } \\
\text { their partners) }\end{array}$ & $\begin{array}{l}\text { Lecture room } \\
\text { in } \\
\text { Sanhujoriwon }\end{array}$ & PI (JES) & 1 session & $120 \mathrm{~min}$ \\
\hline $\begin{array}{l}\text { The 2nd Saturday } \\
\text { after admission } \\
\text { into Sanhujoriwon }\end{array}$ & $\begin{array}{l}\text { - Baby massage and infant care skills } \\
\text { - Expression of love among family members, wife, } \\
\text { partner, and baby } \\
\text { - Supporter's role and strategies to empower and } \\
\text { help mother }\end{array}$ & $\begin{array}{l}\text { Lecture } \\
\text { Practice }\end{array}$ & $\begin{array}{l}\text { Group } \\
\text { (First time } \\
\text { mothers and } \\
\text { their partners) }\end{array}$ & $\begin{array}{l}\text { Lecture room } \\
\text { in } \\
\text { Sanhujoriwon }\end{array}$ & $\begin{array}{l}\text { Coauthor } \\
\text { (JMK) }\end{array}$ & 1 session & $120 \mathrm{~min}$ \\
\hline $\begin{array}{l}\text { Twice a week } \\
\text { during stay within } \\
\text { the Sanhujoriwon }\end{array}$ & $\begin{array}{l}\text { - Counseling and individual education for resolving } \\
\text { breastfeeding difficulties or infant care problems } \\
\text { when rooming-in }\end{array}$ & $\begin{array}{l}\text { Practice } \\
\text { Teaching } \\
\text { Coaching }\end{array}$ & $\begin{array}{l}\text { Individual } \\
\text { family } \\
\text { (First time } \\
\text { mother and } \\
\text { her partner) }\end{array}$ & $\begin{array}{l}\text { Maternal } \\
\text { private room } \\
\text { in } \\
\text { Sanhujoriwon }\end{array}$ & $\begin{array}{l}\text { Coauthor } \\
\text { (JMK) }\end{array}$ & $\begin{array}{l}4 \\
\text { sessions }\end{array}$ & $\begin{array}{l}30 \text { min } \\
\text { for } \\
\text { each } \\
\text { session }\end{array}$ \\
\hline $\begin{array}{l}\text { Before starting } \\
\text { intervention }\end{array}$ & $\begin{array}{l}\text { - Establishing principles to support breastfeeding } \\
\text { and rooming-in for family-centered care } \\
\text { environment }\end{array}$ & $\begin{array}{l}\text { Discussion } \\
\text { Consensus }\end{array}$ & $\begin{array}{l}\text { Individual } \\
\text { (Sanhujoriwon } \\
\text { administrator) }\end{array}$ & $\begin{array}{l}\text { Meeting } \\
\text { room in } \\
\text { Sanhujoriwon }\end{array}$ & PI (JES) & 1 session & $30 \mathrm{~min}$ \\
\hline
\end{tabular}

PI Principle Investigator

\section{Results}

General characteristics of study sample and homogeneity between groups

The 67 mothers ranged in age from 23 to 44 years with a mean of 31 years (standard deviation 4.2 ). The majority of mothers were university graduates $(76.1 \%)$, employed (74.6\%), in the middle economic class (71.6\%) and had given birth vaginally (71.6\%). Mean infant birth weight was $3191 \mathrm{~g}$ (standard deviation 346.7) ranging from 2500 to $3990 \mathrm{~g}$. When the homogeneity test between control and experimental groups was done, there were no significant differences in all general characteristics (Table 3).

\section{Effects of the maternal role adjustment program on maternal role confidence}

There were significant interaction effects (group $\mathrm{x}$ time effect) $(p=.025)$ and time effects $(p<.001)$ in maternal role confidence. In detail, the scores (mean \pm standard deviation) of maternal role confidence in experimental group gradually increased from baseline $(29.37 \pm 6.59)$ to posttest $1(31.43 \pm 5.12)$ and posttest $2(36.30 \pm 5.36)$. This increase was maintained to posttest3 (35.80 \pm 3.71$)$. While, the scores (mean \pm standard deviation) of the control group also increased from baseline $(28.32 \pm 6.14)$ to posttest $1(31.97 \pm 6.13)$ and posttest $2(37.08 \pm 5.52)$, they dropped significantly at posttest $3(32.78 \pm 4.57)$.
So, maternal role confidence scores at posttest 3 (i.e., 12 weeks postpartum) in the experimental group was higher than that of the control group $(t=-2.92, p=.005)$. In addition, time effect among the four measurement times was significant in each group $(p<.001)$ (Table 4, Fig. 2).

\section{Effects of the maternal role adjustment program on breastfeeding success}

In regard to the breastfeeding success scores, there were significant interaction effects (group $\mathrm{x}$ time effect) $(p<.001)$, time effects $(p<.001)$, and group effects $(p<.001)$ when controlling for baseline breastfeeding scores. In detail, the breastfeeding success scores (mean \pm standard deviation) in the experimental group gradually increased from baseline $(2.57 \pm 0.77)$ to posttest $1(3.00 \pm 0.98)$, posttest $2(3.73 \pm 1.28)$, and posttest $3(3.93 \pm 1.51)$. While, the scores (mean \pm standard deviation) of the control group showed similar levels from baseline $(3.73 \pm 0.65)$ to posttest $1(3.76 \pm 0.86)$ and posttest $2(3.78 \pm 1.34)$, but significantly dropped at posttest 3 (3.14 \pm 1.87$)$ (Table 4, Fig. 3). So, the experimental group's breastfeeding success scores were significantly higher than those of control group at both posttest 2 (i.e., 4-6 weeks postpartum) ( $\mathrm{F}=7.97$, $p=.006$ ) and posttest 3 (i.e., 12 weeks postpartum) 
Table 3 General characteristics and homogeneity test between two groups ( $N=67)$

\begin{tabular}{|c|c|c|c|c|c|c|}
\hline Characteristics & Categories & $\begin{array}{l}\text { Total }(\boldsymbol{N}=67) \\
\boldsymbol{n}(\%)\end{array}$ & $\begin{array}{l}\text { Cont. }(\boldsymbol{n}=37) \\
\boldsymbol{n}(\%)\end{array}$ & $\begin{array}{l}\text { Exp. }(\boldsymbol{n}=30) \\
\boldsymbol{n}(\%)\end{array}$ & $x^{2}$ & $p$ \\
\hline Age (years) & $<25$ & $5(7.4)$ & $2(5.4)$ & $1(3.3)$ & 5.88 & .118 \\
\hline$(\mathrm{M} \pm \mathrm{SD}: 31.0 \pm 4.2)$ & $25 \sim 29$ & $21(31.3)$ & $17(45.9)$ & $6(20.0)$ & & \\
\hline \multirow[t]{2}{*}{ (range: $23 \sim 44$ ) } & $30 \sim 34$ & $30(44.8)$ & $14(37.8)$ & $16(53.3)$ & & \\
\hline & $\geq 35$ & $11(16.4)$ & $4(10.8)$ & $7(23.3)$ & & \\
\hline \multirow[t]{2}{*}{ Family type } & Couple only & $65(97.0)$ & 35 (94.6) & $30(100.0)$ & - & $.498^{\dagger}$ \\
\hline & With parents & $2(3.0)$ & $2(5.4)$ & $0(0.0)$ & & \\
\hline \multirow[t]{3}{*}{ Education } & High school & $6(9.0)$ & $5(13.5)$ & $1(3.3)$ & 2.14 & .344 \\
\hline & University & $51(76.1)$ & $27(73.0)$ & $24(80.0)$ & & \\
\hline & Graduate & $10(14.9)$ & $5(13.5)$ & $5(16.7)$ & & \\
\hline \multirow[t]{2}{*}{ Occupation } & No & $17(25.4)$ & $18(48.6)$ & $12(40.0)$ & 0.50 & .479 \\
\hline & Yes & $50(74.6)$ & $19(51.4)$ & $18(60.0)$ & & \\
\hline \multirow[t]{3}{*}{ Economic status } & Middle-low & $10(14.9)$ & $6(16.2)$ & $4(13.3)$ & 0.76 & .684 \\
\hline & Middle & $48(71.6)$ & $25(67.6)$ & $23(76.7)$ & & \\
\hline & Middle-high & $9(13.4)$ & $6(16.2)$ & $3(10.0)$ & & \\
\hline \multirow[t]{2}{*}{ Delivery type } & NSVD & $48(71.6)$ & $23(62.2)$ & $25(83.3)$ & 3.66 & .056 \\
\hline & C-sec & $19(28.4)$ & $14(37.8)$ & $5(16.7)$ & & \\
\hline \multirow[t]{2}{*}{ Baby's gender } & Male & $33(49.3)$ & $9(42.9)$ & $20(58.8)$ & 1.33 & .249 \\
\hline & Female & $34(50.7)$ & $12(57.1)$ & $14(41.2)$ & & \\
\hline Birth weight (gm) & $2500-2999$ & $18(26.9)$ & $10(27.0)$ & $8(26.7)$ & 1.19 & .552 \\
\hline$(\mathrm{M} \pm \mathrm{SD}: 3191.5 \pm 346.7)$ & $3000-3499$ & $35(52.2)$ & $21(56.8)$ & $14(46.7)$ & & \\
\hline (range: $2500 ~ ~ 3990$ ) & $\geq 3500$ & $14(20.9)$ & $6(16.2)$ & $8(26.7)$ & & \\
\hline
\end{tabular}

Cont Control group, Exp Experimental group, M Mean, SD Standard Deviation, NSVD Normal Spontaneous Vaginal Delivery, C-sec Cesarean section

${ }^{+}$Fisher's exact $p$

$(\mathrm{F}=14.31, p<.001)$. In addition, the time effect among the four measurement times were also significant $(p<.001)$ (Table 4, Fig. 4).

\section{Discussion}

This study was conducted to evaluate the effectiveness of a maternal role adjustment program based on the ecological model for first time mothers in Sanhujoriwon on maternal role confidence and breastfeeding success.
In this study, maternal role confidence in the experimental group gradually increased from baseline (Sanhujoriwon admission day) to posttest 1 (Sanhujoriwon discharge day) and 2 (4-6 weeks postpartum), and then maintained to posttest 3 (12 weeks postpartum). While the scores of the control group also increased from baseline to posttest 1 and 2, they dropped significantly at posttest 3. As a result, maternal role confidence in the intervention group was significantly higher than that of the control group at posttest 3.

Table 4 Effects of the maternal role adaptation program $(N=67)$

\begin{tabular}{|c|c|c|c|c|c|c|c|c|c|}
\hline Factors & Group & $n$ & $\begin{array}{l}\text { Baseline } \\
\text { M (SD) }\end{array}$ & $\begin{array}{l}\text { Posttest } 1 \\
\text { M (SD) }\end{array}$ & $\begin{array}{l}\text { Posttest } 2 \\
\text { M (SD) }\end{array}$ & $\begin{array}{l}\text { Posttest } 3 \\
\text { M (SD) }\end{array}$ & $\begin{array}{l}\text { Group } \\
p\end{array}$ & $\begin{array}{l}\text { Time } \\
p\end{array}$ & $\begin{array}{l}\text { Group }{ }^{*} \text { Time } \\
p\end{array}$ \\
\hline \multirow[t]{2}{*}{ Maternal role confidence } & Cont. & 37 & $28.32(6.14)$ & $31.97(6.13)$ & $37.08(5.52)$ & $32.78(4.57)$ & .208 & $<.001$ & .025 \\
\hline & Exp. & 30 & $29.37(6.59)$ & $31.43(5.12)$ & $36.30(5.36)$ & $35.80(3.71)$ & & & \\
\hline $\mathrm{t}(p)$ & & & $-0.67(.506)$ & $0.39(.701)$ & $0.58(.562)$ & $-2.92(.005)$ & & & \\
\hline Breastfeeding success score & $\begin{array}{l}\text { Cont. } \\
\text { Exp. }\end{array}$ & $\begin{array}{l}37 \\
30\end{array}$ & $3.73(0.65) 2.57(0.77)$ & $\begin{array}{l}3.76(0.86) \\
3.00(0.98)\end{array}$ & $\begin{array}{l}3.78(1.34) \\
3.73(1.28)\end{array}$ & $\begin{array}{l}3.14(1.87) \\
3.93(1.51)\end{array}$ & $<.001$ & $<.001$ & $<.001$ \\
\hline $\mathrm{t}(p)$ or $\mathrm{F}^{\mathrm{a}}(p)$ & & & $6.86(<.001)$ & $1.43^{\mathrm{a}}(.236)$ & $7.97^{\mathrm{a}}(.006)$ & $14.31^{\mathrm{a}}(<.001)$ & & & \\
\hline
\end{tabular}

Baseline: 2-7 days after childbirth (the admission day to Sanhujoriwon), Posttest 1: 2-3 weeks after childbirth (the discharge day from Sanhujoriwon), Posttest 2: 46 weeks after childbirth, Posttest 3: 12 weeks after childbirth; Cont. Control group, Exp. Experimental group, M Mean, SD Standard Deviation ${ }^{a} A N C O V A$ test controlling for baseline breastfeeding success score 


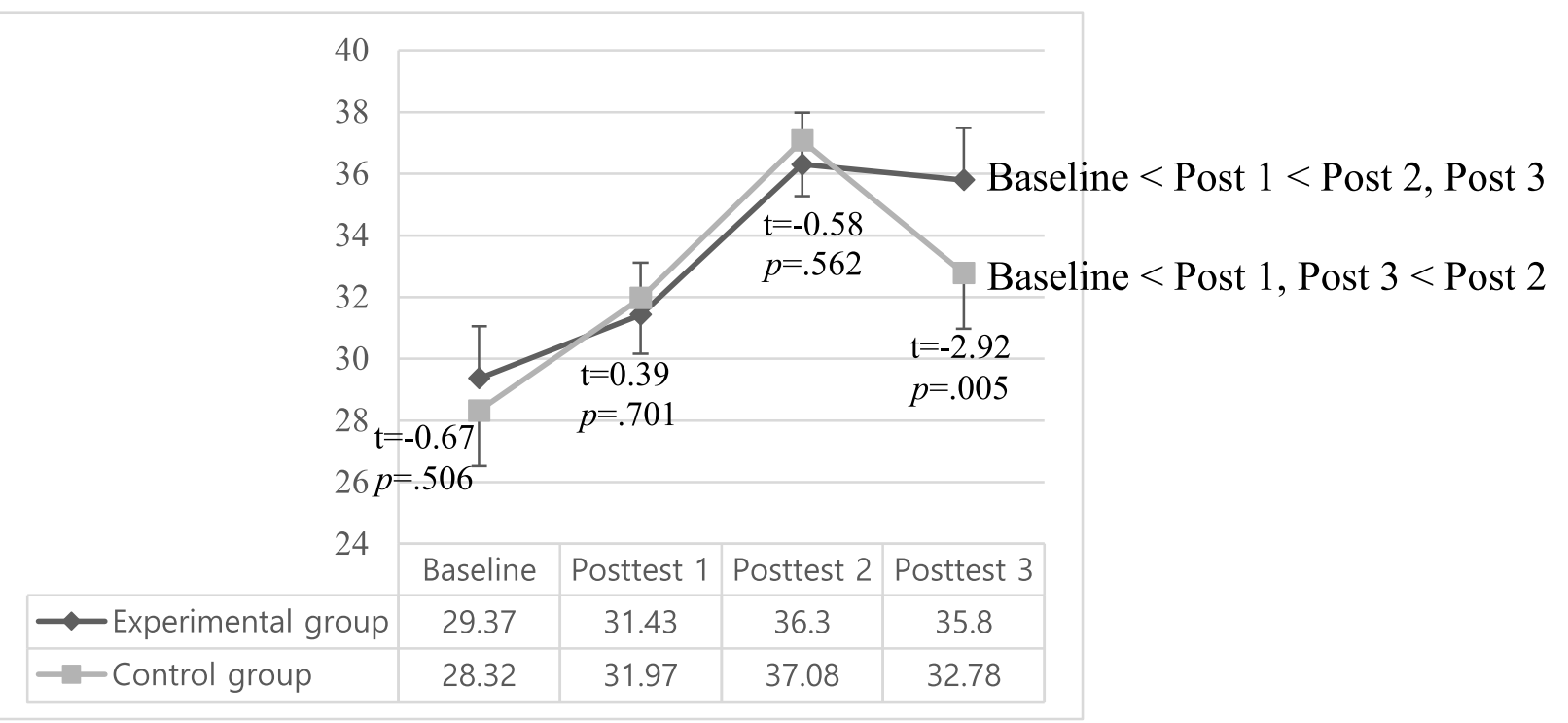

Fig. 2 Mean score changes of maternal role confidence. Baseline: 2-7 day after childbirth (the admission day to Sanhujoriwon), Posttest1: 2-3 weeks after childbirth (the discharge day from Sanhujoriwon), Posttest2: 4-6 weeks after childbirth, Posttest3: 12 weeks after childbirth.

The increase of maternal confidence in both groups from baseline to posttest 1 and 2 was consistent with the results of Shieh et al. [30] and Shorey et al. [31]. Maternal role confidence is associated with cumulative experiences of infant care [32], so mothers in the control group might also increase their maternal role confidence from repeating the daily care for their infants over time [30].

However, in this study maternal role confidence did not increase in both groups from posttest 2 to posttest 3, which is inconsistent with the result of Shorey et al. [31], who reported that maternal confidence gradually increased from baseline to 6 and 12 weeks postpartum in both groups. In most Sanhujoriwon, mothers do not choose rooming-in in order to maximize their physical recovery and most of mothers receive their parents' help for infant care until 4-6 weeks postpartum period even after discharge from the Sanhujoriwon [10]. Thus, the mothers in the control group played a more passive mothering role within a supportive environment until 4-6 weeks postpartum, which may have led mothers to underestimate the real difficulties of the mothering role and overestimate their abilities [10,33]. After 4-6 weeks

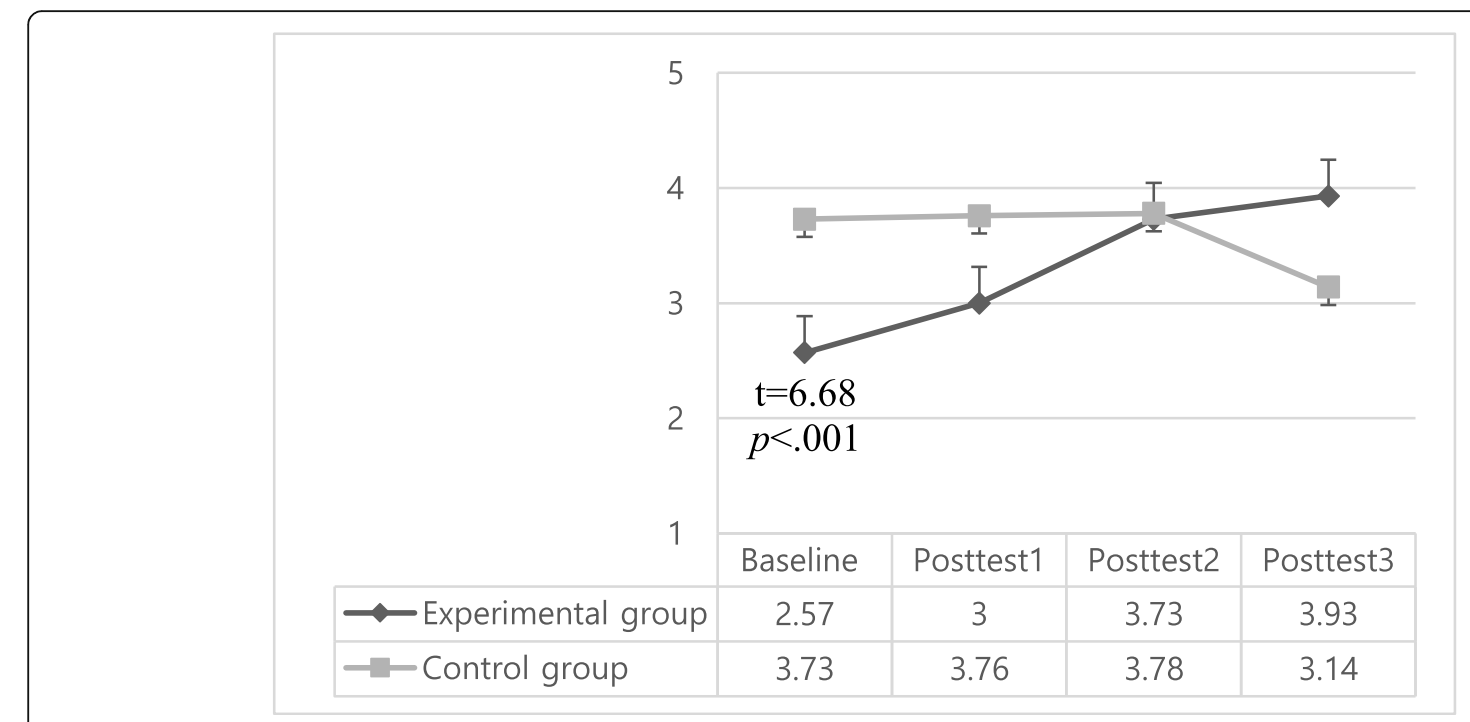

Fig. 3 Mean score changes of breastfeeding success score. Baseline: 2-7 day after childbirth (the admission day to Sanhujoriwon), Posttest1: 2-3 weeks after childbirth (the discharge day from Sanhujoriwon), Posttest2: 4-6 weeks after childbirth, Posttest3: 12 weeks after childbirth. 


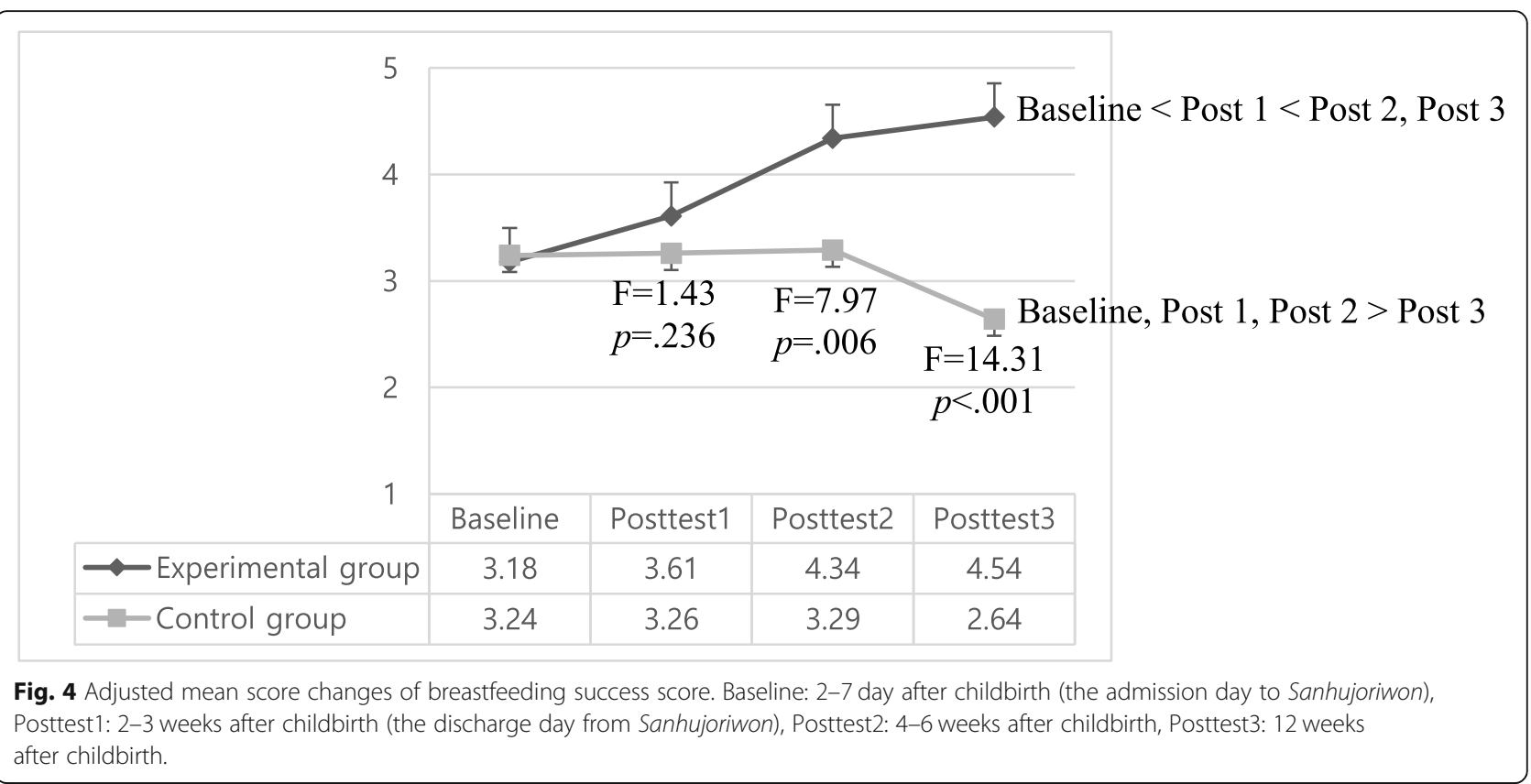

postpartum, as mothers began to care for their infants independently, many experienced significant challenges in the mothering role. Mothers who have repeated negative experiences may have less efficacy with parenting and be less satisfied with her role as a parent [33]. Therefore, it could be inferred that maternal role confidence in the control group decreased at 12 weeks postpartum compared to 4-6 weeks postpartum. On the other hand, mothers in the experimental group performed their mothering role more independently while rooming-in due to the intervention of this study in Sanhujoriwon, which could have had a positive influence on the mother's infant care ability and maternal role confidence after 4-6 weeks postpartum.

Previous studies have found that social support is an important factor enhancing maternal confidence [32, 34] and support from the partner is often the main source of social support for mothers [34]. Recent societal changes in South Korea have led to more nuclear families living together, rather than the previous norms of extended families cohabitating. This change means that the partner has become the most important social support person to new mothers during the first 4-6 weeks postpartum in the average Korean family. However, social support from partners is often inadequate in the postpartum period [35]. Even though partners want to participate in postpartum care, they often do not have enough education or experience in postpartum and infant care to provide substantial help [36]. In this intervention study, we involved the partners in infant care education and gave partners the tools to better assist new mothers as their most important source of social support. We believe this strategy had a positive effect on the maternal role confidence maintenance at posttest 3 in the intervention group.

In this study, breastfeeding success score of the intervention group continuously increased from baseline ( $\mathrm{San}$ hujoriwon admission day) to posttest 3 (12 weeks postpartum), while those of the control group did not show significant changes from baseline to posttest 2 (4-6 weeks postpartum), and dropped at posttest 3 . As a result, breastfeeding success scores of the intervention group were significantly higher than those of the control group at posttest 2 (4-6 weeks postpartum) and posttest 3 (12 weeks postpartum,). The higher breastfeeding success scores of the intervention group at posttest 3 was consistent with the results of Abbass-Dick et al. [37]. Infant feeding is the top concern regarding infant care [10, 38]. Mothers wanted to breastfeed because they perceived breastfeeding to be a natural way of feeding that provides various health benefits for infants and mothers [39]. However, the highest drop-out rate of exclusive breastfeeding is noted in the first month postpartum [40]. Perceived insufficient milk is the main reason for breastfeeding discontinuation worldwide [41-44] and is associated with lack of confidence in breastfeeding and misinterpretation of infant's behavior such as crying [43].

Many mothers perceive infant crying as a sign of hunger and interpret frequent crying to be due to insufficient milk supply. Insufficient milk supply is more likely to be attributed to maternal perception because it is rare to have actual insufficient milk when breastfeeding on demand $[41,45]$. In this study, interventions included face-to-face educations and individual counseling 
regarding infant behaviors such as crying. A more accurate interpretation of infant behavior and response to that through breastfeeding can help first time mothers continue breastfeeding $[46,47]$ and the rooming-in environment in this study help mothers to know their baby's behaviors or cues more effectively [11]. Previous research has shown rooming-in is the most important factor to successful breastfeeding according to the principles of the Baby-Friendly Hospital Initiative [48]. Based on the previous literature, as well as the results in our own work, we believe that encouraging breastfeeding practice within an environment that encourages rooming-in was an effective strategy to improve breastfeeding success scores in the experimental group.

Also, offering breastfeeding educations to fathers likely contributed to the higher level of breastfeeding success in the intervention group compared with the control group. Previous studies have reported that inclusion of fathers in breastfeeding interventions resulted in an increase in breastfeeding duration $[8,37,49]$ and maternal breastfeeding selfefficacy [9]. Educated fathers provided more help with breastfeeding [37]. Based on the results of previous research and this study, we believe fathers can provide major social support for breastfeeding and should be involved in breastfeeding interventions and maternal adjustment programs.

\section{Limitations}

This study was conducted in two postpartum care centers, i.e., Sanhujoriwon located in one city with a quasiexperimental study design. Since randomization was not achieved, we are unable to show causality of the intervention effect on study variables. Further studies using a randomized controlled trial model with more participants living in more cities are warranted. Nevertheless, the results of this novel study were meaningful, as it is the first maternal role adjustment intervention program within a Sanhujoriwon based on the ecological model and the concept of family centered care.

\section{Conclusion}

This study demonstrated the effectiveness of a familycentered care education and counseling intervention encouraging infant care practices and breastfeeding while rooming-in with mothers and partners within postpartum care centers. Approaching the family (mother, partner, and infant) as a unit of care was effective in improving maternal role confidence and breastfeeding success among the first time mothers in two South Korean Sanhujoriwon. Therefore, this program for enhancing healthy interaction amongst mothers, partners, and infants within an environment that encourages roomingin should be actively applied in other postpartum care centers. Future research should be done to evaluate the effectiveness of this intervention using randomized controlled trial methods.

\section{Acknowledgements}

We would like to thank all the first time mothers who participated in this study voluntarily, and the director \& care staff of the postpartum care centers (Sanhujoriwon) who assisted us in the conduct of this experimental study. In addition, we want to thank Dr. Ahn who provided the statistical support for this study.

\section{Authors' contributions}

SJE, CHJ, KJM and YJI conceptualized and designed the study. SJE and KJM performed intervention and data collection. SJE and CHJ performed the statistical analysis of data and interpreted the data. SJE, CHJ, KJM, YJI and TK participated in writing the manuscript and critical revision of the manuscript. SJE, CHJ, KJM, YJI and TK read and approved the final manuscript. SJE received the research grant.

\section{Funding}

This study was financially supported by the National Research Foundation (NRF) of South Korea, the Ministry of Education, Science, and Technology (Grant Number: NRF-2012R1A1A1042257, 2017R1A2B1010362). The funder had no role in the design of the study, intervention, data collection, data analysis, interpretation of data, and writing the manuscript.

\section{Availability of data and materials}

The datasets used and analyzed during the current study are available from the corresponding author on reasonable request.

\section{Ethics approval and consent to participate}

This study was approved by the institutional review board of Ajou University Hospital (AJIRB-MED-SUR-12-268). Information including research purpose, process, compensation for research participation, voluntary participation and withdrawal from the study were given to all participants, and then written informed consents were received from all participants.

Consent for publication

Not applicable.

\section{Competing interests}

The authors declare that they have no competing interests.

\section{Author details}

${ }^{1}$ College of Nursing Research Institute of Nursing Science, Ajou University, Suwon, Republic of Korea. 'Department of Nursing, Joongbu University, 201, Daehak-ro, Chubu-myeon, Geumsan-gun, Chungnam 32713, Republic of Korea. ${ }^{3}$ Department of Nursing, Kookje University, Pyeongtaek, Republic of Korea. ${ }^{4}$ College of Nursing, Ajou University, Suwon, Republic of Korea. ${ }^{5}$ College of Medicine, Ajou University, Suwon, Republic of Korea. ${ }^{6}$ School of Nursing, Bouvé College of Health Sciences, Northeastern University, Boston, USA.

Received: 24 December 2019 Accepted: 3 April 2020

Published online: 16 April 2020

\section{References}

1. Yeh YC, St John W, Venturato L. Doing the month in a Taiwanese postpartum nursing center: an ethnographic study. Nurs Health Sci. 2014; 16(3):343-51.

2. Altuntug K, Anik Y, Ege E. Traditional practices of mothers in the postpartum period: evidence from Turkey. Afr J Reprod Health. 2018;22(1): 94-102.

3. Song JE, Chang SB, Park SM, Kim S, Nam CM. Empirical test of an explanatory theory of postpartum fatigue in Korea. J Adv Nurs. 2010;66(12): 2627-39

4. Choi HK, Jung NO. Factors influencing health promoting behavior in postpartum women at Sanhujoriwon. Korean J Women Health Nurs. 2017; 23(2):135-44.

5. Ministry of Health and Welfare. The government efforts for Sanhujori facility user's damage prevention. 2013. http://www.mw.go.kr/front_new/sch/ index,jsp. Accessed 15 Feb 2019.

6. Lee JL, Son IS, Choi BM, Um JY, Cho ML, Kim HS. Reports for Sanhujori (Korean traditional postpartum care) strategies development for maternal infant health promotion. Seoul: Korean Ministry of Health and Welfare; 2018. 
7. Bsatini $F$, Abadi TA, Haghani $H$. Effect of family-centered care on improving parental satisfaction and reducing readmission among premature infants: a randomized controlled trial. J Clin Diagn Res. 2015;9(1):SC04-8.

8. Ke J, Ouyang YQ, Redding SR. Family-centered breastfeeding education to promote primiparas' exclusive breastfeeding in China. J Hum Lact. 2018; 34(2):365-78.

9. Brockway M, Benzies KM, Carr E, Aziz K. Breastfeeding self-efficacy and breastmilk feeding for moderate and late preterm infants in the family integrated care trial: a mixed mtehods protocol. Int Breastfeed J. 2018;13:29.

10. Song JE, Chae HJ, Park BL. Experiences of Sanhujori facility use among the first time mothers by the focus group interview. Korean J Women Health Nurs. 2015;21(3):184-96.

11. Song JE, Park BL. The changing pattern of physical and psychological health, and maternal adjustment between primiparas who used and those who did not use Sanhujory facilities. J Korean Acad Nurs. 2010;40(4):503-14.

12. Mercer RT. Nursing support of the process of becoming a mother. J Obstet Gynecol Neonatal Nurs. 2006;35(5):649-51.

13. Kim MN, Choi SY. A comparative study of postpartum stress, postpartum depression, postpartum discomfort and postpartum activity, between women who used and those women did not used Sanhujori facilities. J Korean Soc Matern Child Health. 2013;17(2):184-95.

14. Song JE, Ahn JA. Effect of intervention programs for improving maternal adaptation in Korea: systematic review. Korean J Women Health Nurs. 2013; 19(3):129-41.

15. Chae HJ, Kim S. Effects of maternal role practice education on becoming a mother. Korean J Women Health Nurs. 2011;17(1):52-63.

16. Jang S, Kim I. Development of an infants' sleep health program using a video for SIDS prevention education and measurement of the program's effects. Child Health Nurs Res. 2015;21(1):11-9.

17. Yun SE, Lee HK. Effect of breast-feeding adaptation, attitude, and practice of primipara depending on method of postpartum breast-feeding education. Korean J Women Health Nurs. 2012;18(2):75-84.

18. Bronfenbrenner $U$. The ecology of human development: experiments by nature and design. Cambridge: Harvard University Press; 1979.

19. Cross WE. Ecological factors in human development. Child Dev. 2017;88(3):767-9.

20. Derguy C, M'Bailara K, Michel G, Roux S, Bouvard M. The need for an ecological approach to parental stress in autism spectrum disorders: the combined role of individual and environmental factors. J Autism Dev Disord. 2016;46(6):895-905.

21. Kim CJ. Influence of ecological factor of working mothers toward the stress of childcare. Master's thesis. Seoul: Chongshin University; 2009.

22. $\mathrm{Kim} \mathrm{KH}, \mathrm{Cho} \mathrm{BH}$. An ecological approach to analysis of variables in the parenting stress of the dual-earner mothers and fathers. Korean J Child Stud. 2000;20(4):35-50.

23. Sallis JF, Owen N, Fisher EB. Ecological models of health behavior. In: Glanz K, Rimer BK, Viswanath K, editors. Health behavior and health education: theory, research, and practice. 4th ed. San Francisco: Jossey-Bass; 2008. p. 465-85.

24. Saiepour N, Majman JM, Ware R, Baker P, Clavarino AM, Williams GM. Does attrition affect estimates of association: a longitudinal study. J Psychiatr Res. 2019;110:127-42

25. Faul F, Erdfelder E, Lang AG, Buchner A. G* power 3: a flexible statistical power analysis program for the social, behavioral, and biomedical sciences. Behav Res Methods. 2007;39(2):175-91.

26. Pharis ME. Age and sex differences in expectations for infants and the parenting role among couples in a first pregnancy and among university students. Doctoral dissertation. Austin: University of Texas; 1979.

27. Helsing E. Breastfeeding in practice: a manual for health works. Oxford: Oxford Medical Publication; 1985.

28. Park YR. The effects of the integrated breast-feeding education on the knowledge, the adhesiveness and the attitude on breast-feeding. Master's thesis. Incheon: Inha University; 2005.

29. Janke JR. Breastfeeding duration following cesarean and vaginal births. J Nurse Midwifery. 1988;33(4):159-64.

30. Shieh SJ, Chen HL, Liu FC, Liou CC, Lin YH, Tseng HI, Wang RH. The effectiveness of structured discharge education on maternal confidence, caring knowledge and growth of premature newborns. J Clin Nurs. 2010; 19(23-24):3307-13.

31. Shorey S, Chan SW, Chong YS, He HG. A randomized controlled trial of the effectiveness of a postnatal psychoeducation programme on self-efficacy, social support and postnatal depression among primiparas. J Adv Nurs. 2014;71(6):1260-73.
32. Ngai FW, Chan SW, Holroyd E. Chinese pirmiparous women's experiences of early motherhood: factors affecting maternal role competence. J Clin Nurs. 2011;20(9-10):1481-9.

33. Leahy-Warren P, McCarthy G, Corcoran P. First-time mothers: social support, maternal parental self-efficacy and postnatal depression. J Clin Nurs. 2012; 21(3-4):388-97.

34. Shorey S, Chan SW, Chong YS, He HG. Predictors of maternal parental selfefficacy among primiparas in the early postnatal period. West J Nurs Res. 2015;37(12):1604-22

35. Ong SF, Chan WC, Shore S, Chong YS, Klainin-Yobas P, He HG. Postnatal experiences and support needs of first-time mothers in Singapore: a descriptive qualitative study. Midwifery. 2014;30(6):772-8.

36. Joo EK, Yoo EK. Husbands' awareness of Sanhujori, needs for education and family strength. Korean J Women Health Nurs. 2015;21(2):93-105.

37. Abbass-Dick J, Stem SB, Nelson LE, Watson W, Dennis CL. Coparenting breastfeeding support and exclusive breastfeeding: a randomized controlled trial. Pediatrics. 2015;135(1):102-10.

38. Hannan J, Brooten D, Youngblut JM, Galindo AM. Comparing mothers' postpartum concerns in two clinical trials 18 years apart. J Am Assoc Nurse Pract. 2016;28(11):604-11.

39. Ip S, Chung M, Raman G, Trikalinos TA, Lau J. A summary of the agency for healthcare research and quality's evidence report on breastfeeding in developed countries. Breastfeed Med. 2009;4(Suppl 1):S17-30.

40. Centers for Disease Control and Prevention. Pediatric and pregnancy nutrition surveillance system: birth outcome and risk factor analysis. 2015. http://www.cdc.gov/pedness/how_to/read_a_data_table/prevalence_tables/ birth_outcome.htm. Accessed 1 Feb 2019.

41. Brown CR, Dodds L, Legge A, Bryanto J, Semenic S. Factors influencing the reasons why mothers stop breastfeeding. Can J Public Health. 2014;105(3):e179-85.

42. Lenja A, Demissie T, Yohannes B, Yohannis M. Determinants of exclusive breastfeeding practice to infants aged less than six months in Offa district, southern Ethiopia: a cross-sectional study. Int Breastfeed J. 2016;11:32.

43. Wood NK, Sanders EA, Lewis FM, Wood NF, Blackburn ST. Pilot test of a home-based program to prevent perceived insufficient milk. Women Birth. 2017;30(6):472-80

44. Wang W, Lau Y, Chow A, Chan KS. Breast-feeding intention, initiation and duration among Hong Kong Chinese women: a prospective longitudinal study. Midwifery. 2014;30:678-87.

45. Hauck YL, Fenwick J, Dhaliwal SS, Butt J. A Western Australian survey of breastfeeding initiation, prevalence and early cessation patters. Matern Child Health J. 2011;15(2):260-8.

46. Peacock-Chambers E, Dick K, Sarathy L, Brown AA, Boynton-Jarrett R. Perceived maternal behavioral control, infant behavior, and milk supply: a qualitative study. J Dev Behav Pediatr. 2017;38(6):401-8.

47. Wood NK, Woods NF, Blackburn ST, Sanders EA. Interventions that enhance breastfeeding initiation, duration, and exclusivity: a systematic review. MCN Am J Matern Child Nurs. 2016;41(5):299-307.

48. World Health Organization. Guideline: protecting, promoting and supporting breastfeeding in facilities providing maternity and newborn services. Geneva: WHO; 2017.

49. Bich TH, Hoa DT, Malgvist M. Fathers as supporters for improved exclusive breastfeeding in Vietnam. Matern Child Health J. 2014;18(6):1444-53.

\section{Publisher's Note}

Springer Nature remains neutral with regard to jurisdictional claims in published maps and institutional affiliations.

Ready to submit your research? Choose BMC and benefit from:

- fast, convenient online submission

- thorough peer review by experienced researchers in your field

- rapid publication on acceptance

- support for research data, including large and complex data types

- gold Open Access which fosters wider collaboration and increased citations

- maximum visibility for your research: over $100 \mathrm{M}$ website views per year

At $\mathrm{BMC}$, research is always in progress.

Learn more biomedcentral.com/submission 